\title{
Importance of gelatinous plankton organisms in storage and transfer of trace metals in the northwestern Mediterranean
}

\author{
M. Roméo ${ }^{1}$, M. Gnassia-Barelli ${ }^{1}$, C. Carré ${ }^{2}$ \\ ${ }^{1}$ I.N.S.E.R.M., Unité 303, 'Mer et Santé', B.P. 3, F-06230 Villefranche-sur-Mer, France \\ ${ }^{2}$ C.N.R.S URA 716, Observatoire Océanologique, B.P. 28, F-06230 Villefranche-sur-Mer, France
}

\begin{abstract}
Concentrations of trace metals $(\mathrm{Cd}, \mathrm{Cu}, \mathrm{Pb}, \mathrm{Zn})$ were determined in gelatinous macroplankton collected from the northwestern Mediterranean Sea. Samples belonging to 4 different phyla - cnidarians, ctenophores, molluscs and tunicates (salps and pysosomes) - were collected. Some amphipod crustaceans, living on gelatinous organisms, were also analysed. Metal concentrations were basically identical among the different phyla. For the cnidarian Velella velella, differences in cadmium and lead concentrations were noted for organisms of the same weight between those collected near the coast and those from the open sea. In the ctenophore Beroe ovata, copper and zinc concentrations appeared to be independent of weight, whereas some weight-dependency was found in $V$. velella. The most significant features in the trace metal concentration of salps were the elevated values found either in the viscera ('nuclei') or in the faecal pellets, compared to that found in whole animals. Due to their high defecation rate, salps seem to play an important role in the biogeochemical cycling of trace metals in the sea. Cadmium, copper and zinc linked to faecal material may be rapidly dissolved in the water column, whereas lead does not seem to be recycled.
\end{abstract}

\section{INTRODUCTION}

Gelatinous macroplankton constitute an important part of the plankton in oceanic and coastal waters during various times of the year (Alldredge \& Madin 1982). These organisms, at the base of the food web, may significantly mediate the transport and the cycling of metals and radionuclides in oceanic waters (Gorsky et al. 1984, Krishnaswami et al. 1985).

Although almost every major animal group has representatives in the marine zooplankton, most research on trace metal concentrations has focused on crustaceans forms, particularly copepods and euphausiids. The main reason for this is that crustaceans are more abundant all year round and amenable to capture, whereas gelatinous zooplankton organisms are very fragile and are often damaged during collection (the bodies of gelatinous zooplankton contain about $95 \%$ water, compared to about 70 to $87 \%$ for crustacean zooplankton; Curl 1962). Gelatinous organisms represent many phyla, including the cnidarians (hydro- medusae, siphonophores, scyphomedusae), ctenophores, molluscs (heteropods, pteropods) and tunicates (thaliaceans: salps, pyrosomes and doliolids; and appendicularians). Regarding feeding ecology, gelatinous organisms belong to different trophic levels: cnidarians and ctenophores are carnivores, whereas filter-feeding and predatory organisms are found among the molluscs, and thaliaceans are herbivores. The importance of salps in producing large faecal pellets has been emphasized by many authors (Bruland \& Silver 1981, Madin 1982), and these pellets can contribute significantly to the vertical flux of particulate matter to the bottom (Morris et al. 1988).

This study focused on the concentration of trace metals $(\mathrm{Cd}, \mathrm{Cu}, \mathrm{Pb}, \mathrm{Zn})$ in gelatinous macroplankton. Representatives of the major phyla were collected and their trace metal content determined. Some amphipod crustaceans, living on gelatinous organisms, were also analysed with respect to their trace metal concentrations. For salps, the trace metal concentrations of the viscera and the faecal pellets were determined and 
compared to that of specimens as a whole. The purpose of this work was to evaluate the importance of gelatinous plankton in (1) the storage of trace metals and (2) the transport and possible recycling of trace metals through the organisms' particulate products, more precisely through faecal pellets of salps. Trace metals have seldom been measured in gelatinous macroplankton organisms and their particulate products, in contrast to crustaceans (e.g. euphausiids, copepods; Fowler 1977 , Fisher et al. 1983a, Fisher \& Fowler 1987).

\section{MATERIALS AND METHODS}

The sampling area as a whole is characterized by the presence of the Ligurian Current (east to west), which is limited off the coast by a hydrological front, where vertical movements of water masses take place (Béthoux et al. 1988).

Most samples were collected $500 \mathrm{~m}$ from the coast at Stn $B\left(43^{\circ} 41^{\prime} 10^{\prime \prime} N, 7^{\circ} 19^{\prime} \mathrm{E}\right)$ at the entrance of the bay of Villefranche-sur-Mer, at 4 times between 1988 and 1990. Other organisms were sampled at different stations on the Nice-Calvi (Corsica) transect. The first station was located in the Ligurian Current (Stn L1: $43^{\circ} 38^{\prime} 8^{\prime \prime} \mathrm{N}, 7^{\circ} 23^{\prime} 4^{\prime \prime} \mathrm{E}_{\text {; }}$ May 1989) $5.5 \mathrm{~km}$ from the coast (i.e. from Cape Ferrat), the second station (Stn L2: $43^{\circ} 24^{\prime} 8^{\prime \prime} \mathrm{N}, 7^{\circ} 52^{\prime} \mathrm{E}$ ) at 28 miles (ca $50 \mathrm{~km}$ ) from the coast. Two samplings were carried out in May 1991 in the framework of the Medapp cruise (from the RV 'Seward Johnson' Johnson-Sea-Link), one at Stn L2 for the cnidarian chondrophore Velella velella and one at a station termed L'1 $\left(43^{\circ} 34^{\prime} 84^{\prime \prime} N, 7^{\circ} 32^{\prime} 13^{\prime \prime} \mathrm{E}\right)$ for the amphipod Phronima sedentaria, which was situated 10 miles (ca $18 \mathrm{~km}$ ) from the coast where the hydrological front of the Ligurian Sea takes place.

In order to obtain a large number of samples and to limit the damage to such delicate organisms, the sampling protocol differed according to the organism beeing collected. Samples of Velella velella, which float at the surface of the water, were collected using a plastic bucket. The ctenophore Beroe ovata was collected with plastic bags at a depth ranging from 1 to
$10 \mathrm{~m}$. A plankton net $(680 \mu \mathrm{m}$ aperture) was used for molluscs and for thaliacean salps and pyrosomes (horizontal haul between 5 and $10 \mathrm{~m}$ for $15 \mathrm{~min}$ ). To collect Phronima sedentaria (at a depth of $500 \mathrm{~m}$ ) a special pumping device, described in Youngbluth (1984), was used.

After collection, specimens were isolated at room temperature and maintained in an acid-washed aquarium filled with filtered seawater, so that they could eliminate their stomach contents. The samples, which often contained a relatively large number of individuals of one species (especially for salps), were identified, then rinsed briefly with distilled water and stored frozen in plastic vials

For salps (Pegea confoederata and Salpa maxima), the viscera were carefully separated from the tunic of living specimens when possible with a teflon-coated spatula. Otherwise, the faecal pellets, which settled to the bottom of the aquarium, were collected. Prior to analysis, the viscera and faecal pellets were stored frozen as described above.

For analysis, samples were first thawed and then dried at $60^{\circ} \mathrm{C}$ to a constant weight. Digestion of samples was performed in a microwave oven (MDS810) as follows: first, samples were placed in high-pressure vessels, and concentrated nitric acid (65\%) (Merck Suprapur) was added; the digestion procedure then followed 3 steps: microwaving at $30 \mathrm{~W}$ for $15 \mathrm{~min} ; 60 \mathrm{~W}$ for $15 \mathrm{~min}$; and finally $90 \mathrm{~W}$ for $5 \mathrm{~min}$. Metal concentrations were determined by atomic absorption spectrophotometry (Philips Pye Unicam SP9) with flame for copper and zinc and with a graphite furnace for cadmium and lead (Philips PU 9095 video furnace). Deuterium background correction was used when necessary. The analytical procedure was checked regularly using standard reference material (lobster hepatopancreas TORT-1) provided by the National Research Council of Canada.

\section{RESULTS}

Tables 1 to 4 give trace metal concentrations in ctenophores and cnidarians, molluscs, tunicates, and

Table 1. Trace metal concentrations ( $\mu \mathrm{g}$ metal $\mathrm{g}^{-1} \mathrm{dry} w t \pm 1 \mathrm{SD}$ ) in beroid ctenophores and chondrophore cnidarians. n: no. of samples

\begin{tabular}{|llrrrrr}
\hline Species & $\begin{array}{l}\text { Sampling date } \\
\text { and location }\end{array}$ & $\mathrm{n}$ & $\mathrm{Cd}$ & $\mathrm{Cu}$ & $\mathrm{Pb}$ & $\mathrm{Zn}$ \\
\hline Beroe ovata & 25 Mar 1988, Stn B & 15 & $1.4 \pm 0.4$ & $2.8 \pm 0.8$ & $29 \pm 9$ \\
Velella velella & 16 May 1989, Stn B & 20 & $1.3 \pm 0.5$ & $8.9 \pm 2.7$ & $1.2 \pm 1.4$ & $129 \pm 35$ \\
& 16 May 1989, Str L1 & 22 & $2.7 \pm 0.9$ & $9.3 \pm 1.9$ & $0.5 \pm 0.3$ & $100 \pm 18$ \\
& 15 Sep 1989, Stn L2 & 8 & $1.2 \pm 0.5$ & $5.7 \pm 0.7$ & $118 \pm 34$ \\
& 6 May 1991, Stn L2 & 6 & $1.7 \pm 0.2$ & $11.7 \pm 2.3$ & $192 \pm 32$ \\
\hline
\end{tabular}


Table 2. Trace metal concentrations ( $\mu \mathrm{g}$ metal $\mathrm{g}^{-1} \mathrm{dry}$ wt $\pm 1 \mathrm{SD}$ ) in molluscs (gastropods: thecosomes and gymnosomes). n: no. of samples

\begin{tabular}{|c|c|c|c|c|c|c|}
\hline Species & $\begin{array}{l}\text { Sampling date } \\
\text { and location }\end{array}$ & $\mathrm{n}$ & $\mathrm{Cd}$ & $\mathrm{Cu}$ & $\mathrm{Pb}$ & $\mathrm{Zn}$ \\
\hline \multicolumn{7}{|l|}{ Thecosomes } \\
\hline \multirow[t]{5}{*}{ Cavolinia inflexa } & 25 Mar 1988, Stn L2 & 2 & 2.4 & 3.6 & & 184 \\
\hline & & & 2.4 & 5.1 & & 205 \\
\hline & 14 Apr $1989, \operatorname{Stn} B$ & 2 & 0.4 & 1.4 & 3.0 & 81 \\
\hline & & & 1.1 & 1.3 & 3.0 & 52 \\
\hline & 16 May 1989, Stn L1 & 3 & $1.4 \pm 0.6$ & $1.8 \pm 0.2$ & $3.0 \pm 0.1$ & $96 \pm 17$ \\
\hline Clio pyramidata & 25 Mar 1988, Stn L2 & 3 & $3.1 \pm 1.0$ & $3.1 \pm 0.2$ & & $242 \pm 22$ \\
\hline \multicolumn{7}{|l|}{ Gymnosomes } \\
\hline \multirow[t]{4}{*}{ Pneumodermopsis canephora } & 25 Mar 1988, Stn L2 & 1 & 3.9 & 8.7 & & 325 \\
\hline & 14 Apr $1989, \operatorname{Stn} B$ & 2 & 1.2 & 4.6 & 3.0 & 106 \\
\hline & & & 6.9 & 9.4 & 3.0 & 118 \\
\hline & 16 May 1989, Stn L1 & 4 & $1.5 \pm 0.2$ & $3.3 \pm 1.0$ & $3.0 \pm 0.0$ & $109 \pm 61$ \\
\hline \multicolumn{3}{|c|}{ Concentration range in all the molluscs } & $0.4-6.9$ & $1.3-9.4$ & $2.8-3.2$ & $52-325$ \\
\hline
\end{tabular}

Table 3. Trace metal concentrations ( $\mu$ g metal $\mathrm{g}^{-1} \mathrm{dry}$ wt $\pm 1 \mathrm{SD}$ ) in tunicates (thaliaceans: pyrosomes and salps). n: no. of samples

\begin{tabular}{|c|c|c|c|c|c|c|}
\hline Sample & $\begin{array}{l}\text { Sampling date } \\
\text { and location }\end{array}$ & $\mathrm{n}$ & $\mathrm{Cd}$ & $\mathrm{Cu}$ & $\mathrm{Pb}$ & $\mathrm{Zn}$ \\
\hline Pyrosoma atlanticum & $\begin{array}{l}16 \text { May } 1989, \text { Stn B } \\
11 \text { Jan } 1990, \text { Stn B }\end{array}$ & $\begin{array}{l}1 \\
1\end{array}$ & 4.3 & $\begin{array}{l}12.4 \\
12.4\end{array}$ & 3.9 & $\begin{array}{l}135 \\
191\end{array}$ \\
\hline Pegea confoederata & 16 May 1989, Stn L1 & 5 & $0.3 \pm 0.0$ & $11.9 \pm 1.3$ & $4.5 \pm 2.5$ & $51 \pm 4$ \\
\hline Faecal pellets of $P$. confoederata & 16 May $1989, \operatorname{Stn} L 1$ & 3 & $2.1 \pm 0.0$ & $59.3 \pm 18.1$ & & $352 \pm 25$ \\
\hline Thalia democratica & $\begin{array}{l}14 \text { Apr } 1989, \text { Stn B } \\
14 \text { Apr } 1989, S \operatorname{Stn} B \\
16 \text { May } 1989, S \operatorname{Stn} B \\
16 \text { May } 1989, S \operatorname{Stn} \text { B } \\
\text { Mean value }\end{array}$ & $\begin{array}{l}1 \\
1 \\
1 \\
1 \\
4\end{array}$ & $\begin{array}{c}0.1 \\
0.3 \\
0.1 \\
0.3 \\
0.2 \pm 0.1\end{array}$ & $\begin{array}{c}6.4 \\
26.0 \\
8.6 \\
15.3 \\
14.1 \pm 8.8\end{array}$ & $\begin{array}{c}2.0 \\
0.5 \\
0.6 \\
5.8 \\
2.2 \pm 2.5\end{array}$ & $\begin{array}{c}32 \\
48 \\
24 \\
99 \\
51 \pm 34\end{array}$ \\
\hline Salpa maxima & 25 Mar $1988, \operatorname{Stn}$ L2 & 3 & $1.7 \pm 1.4$ & $2.5 \pm 1.0$ & & $20 \pm 8$ \\
\hline Faecal pellets of $S$ maxima & 25 Mar 1988, Stn L2 & 1 & 4.3 & 15.0 & & 118 \\
\hline Salpa maxima & $12 \operatorname{Jan} 1990, \operatorname{Stn} B$ & 12 & $0.4 \pm 0.4$ & $5.9 \pm 2.4$ & & $79 \pm 20$ \\
\hline Nucleus of S. maxima & $12 \operatorname{Jan} 1990, \operatorname{Stn} B$ & 6 & $1.4 \pm 0.3$ & $18.3 \pm 5.9$ & $22.9 \pm 24.2$ & $125 \pm 37$ \\
\hline Faecal pellets of $S$. maxima & 12 Jan $1990, \operatorname{Stn} B$ & 7 & $0.7 \pm 0.6$ & $45.8 \pm 11.7$ & $65.9 \pm 16.5$ & $216 \pm 66$ \\
\hline Salpa fusiformis & $\begin{array}{l}25 \text { Mar } 1988, \text { Stn L2 } \\
12 \text { Jan } 1990, \text { Stn B }\end{array}$ & $\begin{array}{l}4 \\
4\end{array}$ & $\begin{array}{l}0.2 \pm 0.1 \\
1.1 \pm 1.0\end{array}$ & $\begin{array}{l}6.4 \pm 2.0 \\
6.6 \pm 4.9\end{array}$ & $2.6 \pm 2.0$ & $\begin{array}{l}22 \pm 7 \\
64 \pm 28\end{array}$ \\
\hline Ihlea punctata & 25 Mar 1988, Stn L2 & 4 & $0.7 \pm 0.2$ & $2.3 \pm 0.3$ & & $18 \pm 3$ \\
\hline
\end{tabular}

Table 4. Trace metal concentrations ( $\mu$ g metal $g^{-1}$ dry wt \pm 1 SD) in hyperiid amphipods. $n$ : no. of samples

\begin{tabular}{|llccccc}
\hline Sample & $\begin{array}{l}\text { Sampling date } \\
\text { and location }\end{array}$ & $\mathrm{n}$ & $\mathrm{Cd}$ & $\mathrm{Cu}$ & $\mathrm{Pb}$ & $\mathrm{Zn}$ \\
\hline Vibilia armata & 25 Mar 1988, Stn L2 & 1 & 4.0 & 59.0 & 141 \\
Phronima sedentaria & 25 Mar 1988, Stn L2 & 1 & 8.8 & 17.6 & 108 \\
Barrel (pyrosome) of P. sedentaria & 8 May 1991, Stn L'1 & 6 & $2.7 \pm 1.0$ & $24.3 \pm 6.1$ & $149 \pm 27$ \\
\hline
\end{tabular}


amphipod crustaceans (living on gelatinous organisms), respectively. The high standard deviations of the means show that results were variable. Metal concentrations were generally identical among the different phyla. Compared to the other species studied, the ctenophore Beroe ovata (Table 1) contained low concentrations of zinc. Cadmium seemed to be particularly concentrated in some Velella velella (collected at Stn L1; Table 1), some molluscs (Table 2) and all the amphipod crustaceans (Table 4). For whole salps (Table 3), cadmium and zinc concentrations were relatively low.

All samples of Beroe ovata were collected on the same date at the same coastal station (Table 1). Size and weight of the samples differed. An allometric approach was attempted. Trace metal contents (expressed as $\mu \mathrm{g}$ dry wt) per individual were plotted versus dry weight (in $\mathrm{g}$ ) as the power function $Y=a \mathrm{~W}^{b}$ (or $\log Y=\log a+b \log W$ ), where $\mathrm{W}=$ weight. The most significant relationships were found for copper $(b=1.007 \pm 0.145, a=2.54 ; r=0.945$ at $p<0.001)$ and for zinc $(b=0.844 \pm 0.107, a=29 ; \mathrm{r}=0.944$ at $\mathrm{p}<0.001$ ), and are shown in Fig. 1. Values for cadmium were not reported due to the large error in evaluating $b$. The residual variance associated with slope $b$ was computed; the slope was then compared to a theoretical slope of 1 by means of a $t$-distribution. The results
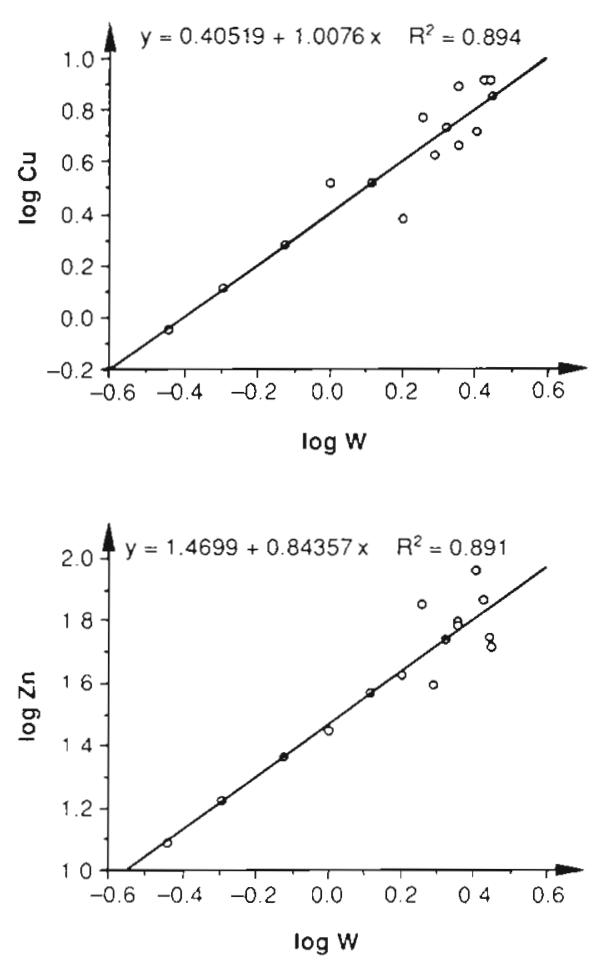

Fig. 1. Beroe ovata. Relationship $\log C=\log a+b \log W$; copper and zinc contents $(C)$ are expressed in $\mu \mathrm{g}$ ind. ${ }^{-1}$, dry weight (W) in $g$ showed that the slope was not significantly different from 1 since $t=0.084$ for $\mathrm{Cu}$ and -2.048 for $\mathrm{Zn}$, values lower than $t=4.221$ given by a $t$-distribution with 13 degrees of freedom at $p<0.001$.

The large sample size of Velella velella (Table 1) mean that for the same sampling date (16 May), a direct comparison could be made between the results obtained at Stn B ( $(=20)$ and those at Stn L1 $(n=22)$. In addition, this was made easier because the size of organisms and their dry weight did not differ significantly (mean dry weight $=160 \pm 50 \mathrm{mg}$ at Stn B and $140 \pm 70 \mathrm{mg}$ at Stn L1; $t$-test non significant). $V$. velella collected at Stn L1 had a higher mean cadmium concentration than those at Stn B ( $t$-test significant at $p<0.001$ ). Lead concentrations were higher at Stn B than at Stn L1, but the means were not significantly different. At Stn L2, weights of specimens collected in September 1989 were low $(67 \pm 2 \mathrm{mg})$, and of those collected in May 1991 were high $(221 \pm 70 \mathrm{mg}$ ). The relationships $Y=a \mathrm{~W}^{b}$, as mentioned above, were calculated for copper $(b=1.419 \pm 0.097, a=19.62$; $\mathrm{r}=0.973$ at $\mathrm{p}<0.001)$ and zinc $(b=1.399 \pm 0.094$, $a=346 ; r=0.974)$. The slopes were significantly different from 1 ( $t=4.655$ for $\mathrm{Cu}$ and 4.538 for $\mathrm{Zn}$, values higher than $t=4.318$ given by a $t$-distribution with 12 degrees of freedom at $p<0.001$ )

Among the tunicates, the most significant features in the trace metal concentration of salps (Table 3) were the elevated values found in either the nuclei or the faecal pellets compared to that found in whole animals. The cadmium and copper concentrations in the nuclei of Salpa maxima were significantly higher (by factors of 5 and 3 respectively; $t$-tests significant at $p<0.001$ ) than in whole animals. For zinc, the difference was not significant. For Pegea confoederata, faecal pellets were richer in cadmium, copper and zinc (by factors of 7,5 and 7 respectively; $t$-test significant at $p<0.001$ ) than the animals themselves. For $S$. maxima collected in March 1988 at Stn L2, only one sample of faecal pellets could be analysed, rendering any interpretation difficult, whereas in January 1990 at Stn B, more samples of both organisms and faecal pellets were available. From these, copper and zinc were shown to be particularly concentrated in the faecal pellets (by factors of 8 and 2.5 respectively; $t$-test significant at $\mathrm{p}<0.001)$ compared to whole animals. Metal concentrations for $S$. maxima were lower in nuclei than in faecal pellets; this was particularly significant in the case of copper $(t=5.18, \mathrm{p}<0.001)$, and less significant in the case of zinc. When dissecting the animals, it was very difficult to separate the nuclei from the tunic surrounding them. The tunic is mainly constituted of seawater and tunicin. Tunicin is a form of cellulose specific to tunicates (Madin et al. 1981). Analyses performed on the tunic itself, collected from some 
S. maxima samples, showed low concentrations of copper $\left(2 \mu \mathrm{g} \mathrm{g}^{-1}\right)$ and zinc $\left(40 \mu \mathrm{g} \mathrm{g}^{-1}\right)$; cadmium and lead concentrations were below the detection limit.

Amphipod crustaceans generally displayed higher cadmium and copper concentrations (Table 4) than the 4 other phyla studied. The barrel, consisting of the transformed body of a pyrosome in which Phronima sedentaria lived (Laval 1978), exhibited very low values of metals, even lower than that found for Pyrosoma atlanticum (Table 3); concentrations found in the barrel were very similar to those reported for the tunic.

\section{DISCUSSION}

Comparison of the results obtained in this study with those given in the literature is difficult, since very few data are available. Siphonophores (hydrozoairs), cnidarians which are taxonomically near the chondrophore Velella velella, have been studied with respect to their metal concentrations by Fowler et al. (1985) and Roméo et al. (1987). The data, presented in
Table 5, are in good agreement with this work. Moreover, trace metal concentrations in the salps Thalia democratica, Salpa maxima, S. fusiformis and Pyrosoma atlanticum, collected from the northwestern Mediterranean Sea (Fowler et al. 1985, Krishnaswami et al. 1985. Roméo et al. 1987), are also very similar.

Differences found in cadmium and lead concentrations in Velella velella, collected at Stns B and L1, may reflect concentrations in surface waters since $V$. velella floats at the very surface of the water Enrichment of trace metals has been observed in surface microlayer seawater as compared to subsurface seawater (Hunter 1980). Stn L1 is situated in the Ligurian Current, which transports dissolved and particulate pollutant metals from Genova and La Spezia, and Stn B is in the coastal area. Concerning lead, Roméo et al. (1985) found significantly higher concentrations in copepods and mixed gelatinous macroplanktonic organisms collected at Stn B than in those at stations located on the NiceCalvi transect. This phenomenon was ascribed by the authors to contamination of coastal waters by atmospheric lead from car exhaust emissions.

Table 5. Trace metal concentrations ( $\mu \mathrm{g}$ metal $\mathrm{g}^{-1} \mathrm{dry}$ wt) in gelatinous macroplankton organisms from different locations. DL: detection limit

\begin{tabular}{|c|c|c|c|c|c|c|}
\hline Taxon & Location & $\mathrm{Cd}$ & $\mathrm{Cu}$ & $\mathrm{Pb}$ & $\mathrm{Zn}$ & Source \\
\hline \multicolumn{7}{|l|}{ Tunicates: thaliaceans } \\
\hline $\begin{array}{l}\text { Thalia democratica } \\
\text { Salpa maxima }\end{array}$ & NW Mediterr. & & $\begin{array}{c}17.0-22.4 \\
7.3\end{array}$ & & $\begin{array}{c}93-312 \\
35.6\end{array}$ & $\begin{array}{l}\text { Krishnaswami } \\
\text { et al. (1985) }\end{array}$ \\
\hline $\begin{array}{l}\text { Thalia democratica } \\
\text { and Salpa fusiformis }\end{array}$ & NW Mediterr & DL & 3.4 & 1.7 & 17 & Roméo et al. (1987) \\
\hline Salps & NW Mediterr. & $0.1-3.4$ & $1.7-26.0$ & $0.5-6.4$ & $12-117$ & Present study \\
\hline \multicolumn{7}{|l|}{ Salps } \\
\hline $\begin{array}{l}\text { Salpa maxima } \\
\text { Pyrosoma atlanticum }\end{array}$ & Mediterranean & $\begin{array}{l}0.12-0.23 \\
0.10-0.21\end{array}$ & $\begin{array}{l}7.6-10.4 \\
8.7-13.4\end{array}$ & & $\begin{array}{l}26-54 \\
64-180\end{array}$ & Fowler et al. (1985) \\
\hline Cnidarians: siphonophores & $\begin{array}{l}\text { NW Mediterr. } \\
\text { Mediterranean }\end{array}$ & $\mathrm{DL}-1.8$ & DL -8.3 & DL- -2.7 & $\begin{array}{c}24-69 \\
25\end{array}$ & $\begin{array}{l}\text { Roméo et al. (1987) } \\
\text { Fowler et al. (1985) }\end{array}$ \\
\hline \multicolumn{7}{|l|}{ Cnidarians: chondrophores } \\
\hline Velella velella & NW Mediterr. & $0.7-4.7$ & $4.7-16.6$ & $0.1-5.2$ & $55-260$ & Present study \\
\hline \multicolumn{7}{|l|}{ Ctenophores } \\
\hline Beroe ovata & N Atlantic & 0.16 & 2.0 & & 52 & Dubé (1982) \\
\hline Beroe ovata & NW Mediterr. & $0.8-2.0$ & $1.5-4.4$ & & $18-48$ & Present study \\
\hline Crustaceans: copepods & NW Mediterr. & 1.7 & 24.1 & 1.9 & 227 & Roméo (1985) \\
\hline \multicolumn{7}{|l|}{ Crustaceans: amphipods } \\
\hline $\begin{array}{l}\text { Phrosina semilunata } \\
\text { Phronima sedentaria }\end{array}$ & NW Mediterr. & $\begin{array}{l}5.8-7.5 \\
2.0-8.8\end{array}$ & $\begin{array}{l}21.6-26.7 \\
17.6-34.9\end{array}$ & & $\begin{array}{l}109-190 \\
108-197\end{array}$ & $\begin{array}{l}\text { Fowler (1986) } \\
\text { Present study }\end{array}$ \\
\hline $\begin{array}{l}\text { Parathemisto pacifica } \\
\text { and P. libellula }\end{array}$ & N Pacific & 8.28 & & & 106 & $\begin{array}{l}\text { Hamanaka \& } \\
\text { Tsujita (1981) }\end{array}$ \\
\hline Themisto compressa & NE Atlantic & 69.5 & 38.6 & & 76.3 & Rainbow (1989) \\
\hline
\end{tabular}


In molluscs, Boyden $(1974,1977)$ identified 3 relationships $\left(Y=a W^{b}\right)$ between trace element content and body weight. First, element content was related to $b=0.77$ as the power of body weight, or to $b=-0.23$ when using the weight-specific relationship $Y^{\prime}\left(\mu \mathrm{g} \mathrm{g}^{-1}\right)$ $=Y / W=a W^{b-1}$. Small individuals would contain higher concentrations of metals than larger individuals, thus indicating some relationship between uptake and surface area. A value of $b>1$ indicates that metal concentration increases with increasing weight, but where $b$ is close to 1.00 , metal concentrations are independent of weight and metals may be linked to the major biochemical constituent of the organism. In the case of the ctenophore Beroe ovata, $b$ is close to 1.00 for copper and zinc; the major biochemical constituent, mesogleal collagen (Trégouboff \& Rose 1957), thus may absorb these essential trace metals. However, it is difficult to determine whether they are absorbed directly from seawater or from ingested prey consisting mainly of other ctenophores (Hoeger 1983). In the cnidarian Velella velella, caught at the open-sea station $\mathrm{L} 2$ but on 2 different dates, $b$ is $>1.00$; this may be indicative of further accumulation of body metal after cessation (or slowing down) of growth. A similar value of $b$ was also found for copper in a euphausiid crustacean, Meganyctiphanes norvegica, collected in the northeast Atlantic (Rainbow 1989).

In general, trace metal concentrations in the animals studied may be related to their feeding ecology. For instance, no difference in metal concentrations was found between gymnosome and thecosome molluscs, which are filter-feeding (Table 2). In fact, thecosome molluscs probably collect detrital as well as living particles. Gymnosome molluscs prey on thecosome molluscs, and Pneumodermopsis canephora is the specific predator of Cavolinia inflexa, so it is not surprising that their tissues have similar metal contents. Among the amphipod crustaceans, the sample of Vibilia armata analysed seemed to have higher metal concentrations than the salps, upon which this species feeds. The trace metal concentrations in Phronima sedentaria were of the same order of magnitude as those in Pyrosoma atlanticum, on which the amphipods live and feed. The low metal concentrations found in the barrel of Phronima sedentaria might have been due to the fact that this species consumed all the digestive tracts of the zooids constituting the colony of the pyrosome, leaving only the tunic. The concentrations reported here for amphipod crustaceans are close to those found by Fowler (1986) in the northwestern Mediterranean and by Hamanaka \& Tsujita (1981) in the North Pacific (Table 5). Rainbow (1989) observed that amphipods of the genus Themisto accumulate atypically high body concentrations of cadmium (ca 60 $\mu \mathrm{g} \mathrm{Cd} \mathrm{g^{-1 }}$. He suggested that these high concentra- tions may be a consequence of the amphipods' diet or of some strong physiological affinity for the metal. The nuclei of the salps studied were full of phytoplankton. Salps are herbivores and feed on diatoms, flagellates, and other phytoplankton species, as well as detritus (Braconnot 1971, Alldredge \& Madin 1982). Metal concentrations in nuclei of Salpa maxima (Table 3) were comparable to those found in phytoplankton (Roméo \& Nicolas 1986).

Trace metal concentrations in the different phyla may be compared on a biomass basis. The variation in the biomass of different zooplankton groups collected on a transect between Nice and Calvi, and especially of the 2 important groups copepods and salps, has been reported by Baker (1990). In this area, the biomass of copepods decreased from 397 (March) to $242 \mathrm{mg} \mathrm{m}^{-2}$ (May), whereas the biomass of salps increased from 13 (March) to $756 \mathrm{mg} \mathrm{m}^{-2}$ (May). Using previously collected data (shown in Table 5) on trace metals in copepods (Roméo 1985) and the data presented here for salps, the respective contributions of these 2 groups to the concentration of metals (for instance cadmium and zinc) in the sea may be calculated. In March, this contribution was much higher for copepods $\left(0.67 \mu \mathrm{g} \mathrm{Cd} \mathrm{m}^{-2}\right.$ and $\left.90 \mu \mathrm{g} \mathrm{Zn} \mathrm{m}^{-2}\right)$ than for salps $\left(0.010 \mu \mathrm{g} \mathrm{Cd} \mathrm{m}^{-2}\right.$ and $\left.0.68 \mu \mathrm{g} \mathrm{Zn} \mathrm{m}^{-2}\right)$ whereas it was similar for copepods and salps (ca $0.4 \mu \mathrm{g} \mathrm{Cd} \mathrm{m}{ }^{-2}$ and ca $40 \mu \mathrm{g} \mathrm{Zn}^{-2}$ ) in May. Thus, salps can contribute significantly to the trace metal 'total burden' in the sea at some times of the year.

Very few data are available on trace metal concentrations in salp faecal pellets. Krishnaswami et al. (1985) collected salps and faecal pellets near the coastal sampling area studied in this work and found that the concentrations of $\mathrm{Fe}, \mathrm{Al}$, Th isotopes ( ${ }^{224} \mathrm{Th}$, ${ }^{228} \mathrm{Th}$ and ${ }^{232} \mathrm{Th}$ ) and ${ }^{210} \mathrm{~Pb}$ in faecal pellets were about 1 order of magnitude higher than those in salps. Concentrations of $\mathrm{Ca}, \mathrm{Cu}, \mathrm{Zn}, \mathrm{Mn}$ and Po were also higher, by factors of about 2 to 5. Krishnaswami et al. (1985) found concentrations of $34.3 \mu \mathrm{g} \mathrm{Cu} \mathrm{g}{ }^{-1}$ and $196 \mu \mathrm{g}$ $\mathrm{Zn} \mathrm{g}^{-1}$ in faeces of Salpa maxima; such values are in good agreement with those in study. Caron et al. (1989) reported higher values of copper in one sample of Pegea bicaudata faeces ( $744 \mu \mathrm{g} \mathrm{Cu} \mathrm{g}^{-1}$ ) and 3 samples of $S$. maxima $\left(217 \mu \mathrm{g} \mathrm{Cu} \mathrm{g}{ }^{-1}\right)_{i}$ nevertheless, concentrations of copper in whole salps were not given by these authors, which makes comparison of results difficult.

Bruland \& Silver (1981) noted the extraordinarily high sinking rates of salp faecal pellets and indicated that these tunicates may be disproportionately important in the flux of biogenic materials during periods when they form dense population blooms. Andersen \& Nival (1988) reported that, after a $40 \mathrm{~d}$ simulation period of production and sedimentation of biogenic particles, faecal pellets of salps and copepods con- 
stituted $65 \%$ of the material in a sediment trap. According to these authors, although salp and copepod biomasses were similar during the study period, the magnitude and composition of the particle flux were influenced much more by salps than by copepods. Moreover, in the sampling area studied here, on a transect from 3 to 28 miles (ca 5 to $50 \mathrm{~km}$ ) off Villefranche-sur-Mer, Nival et al. (1985) concluded on the basis of the distribution of salps Salpa fusiformis (uniform repartition or aggregation on a vertical profile) that these organisms are responsible to some extent for the decay of phytoplankton at the end of spring.

To evaluate the transfer of metals to sediments, which are considered as reservoirs of pollutants, metal concentrations in salp faeces (global means calculated from Table 3: $1.3 \mu \mathrm{g} \mathrm{Cd} \mathrm{g}^{-1}, 47 \mu \mathrm{g} \mathrm{Cu} \mathrm{g}^{-1}$, $62 \mu \mathrm{g} \mathrm{Pb} \mathrm{g}{ }^{-1}$, and $224 \mu \mathrm{g} \mathrm{Zn}^{-1}$ ) were compared to those reported for particulate material collected in a sediment trap placed at a depth of $200 \mathrm{~m}$ in a Mediterranean coastal area (Roméo et al. 1988). Concentrations in sediment (transformed into $\mu \mathrm{g}_{\text {metal }} \mathrm{g}^{-1}$ dry wt) were $0.7 \mu \mathrm{g} \mathrm{Cd} \mathrm{g}^{-1}, 46 \mu \mathrm{g} \mathrm{Cu} \mathrm{g}^{-1}, 274 \mu \mathrm{g}$ $\mathrm{Pb} \mathrm{g}^{-1}$ and $150 \mu \mathrm{g} \mathrm{Zn} \mathrm{g}^{-1}$. Ratios of the metal concentration in particulate material to that in salp faeces were $\leq 1$ for cadmium, copper and zinc but reached ca 4 in the case of lead. The explanation for this may be that cadmium, copper and zinc linked to salp faecal pellets are rapidly dissolved and may return to the biological cycle. Lead, on the other hand, does not seem to be recycled.

Biogeochemical implications of zooplankton-derived sinking material have been recently studied (Fisher et al. 1991a, b, Reinfelder \& Fisher 1991). Fisher et al. (1991a) evaluated the retention efficiencies of excreted metals in faecal pellets and suggested that cadmium, zinc and mercury might be recycled by copepods in surface waters as part of the organic cycle in the sea, while the transuranic elements might be defecated and removed from surface waters by sinking biogenic debris. Reinfelder \& Fisher (1991) also demonstrated a direct correlation between the retention efficiency of ingested elements (C, Se, P, $\mathrm{Cd}, \mathrm{Ag}, \mathrm{Am}, \mathrm{Zn}, \mathrm{S})$ in copepods and the presence of these elements in the cytoplasm of the copepods' diatom food. This suggests that the copepods obtained all their nutrition from the cytosol. Other elements such as lead, which largely remain bound to the surface of algal cells (Fisher et al. 1983b), are not assimilated, being eliminated in faecal pellets (Fowler 1977). These elements undergo negligible recycling and have a comparatively short residence time in surface waters. Our results on salp faecal pellets are in good agreement with these various studies.
Acknowledgements. This work was partly supported by FAO-MEDPOL (Mediterranean Action Plan: Pollution Monitoring and Research Programme), FRA/40 K. The authors are grateful to Dr A. Pacey for help with the English translation, and to Dr N. S. Fisher and the anonymous referees.

\section{LITERATURE CITED}

Alldredge, A. L., Madin, L. P. (1982). Pelagic tunicates: unique herbivores in the marine plankton. BioSci. 32: 655-663

Andersen, V., Nival, P. (1988). A pelagic ecosystem model simulating production and sedimentation of biogenıc particles: role of salps and copepods. Mar. Ecol. Prog. Ser 44: $37-50$

Baker, M. (1990). Estimation du bilan de matière dans l'écosystème pélagique en mer Ligure (Méditerranée occidentale). Application aux missions Dyfamed et Trophos II. Etude expérimentale sur les Salpes. Thèse, Université de Paris VI

Béthoux, J. P., Prieur, L., Bong, J. H. (1988). Le courant Ligure au large de Nice. Oceanol. Acta Spec. Issue: 59-67

Boyden, C. R. (1974). Trace element content and body size in molluscs. Nature, Lond. 252: 311-314

Boyden, C. R. (1977). Effect of size upon metal content of shellfish. J. mar. biol. Ass. U.K. 57:675-714

Braconnot, J C. (1971). Contribution à l'étude biologique et écologique des tuniciers pélagiques Salpides et Doliolides. I. Hydrologie et écologie des Salpides. Vie Milieu 22: 257-286

Bruland, K. W., Silver, M. W. (1981). Sinking rates of faecal pellets from gelatinous zooplankton (salps, pteropods, doliolidsj. Mar. Biol. 63: 295-300

Caron, D. A., Madin, L. P., Cole, J. J. (1989). Composition and degradation of salp fecal pellets; implications for vertical flux in oceanic environments. J. mar. Res. 47: 829-850

Curl, H. Jr (1962). Standing crops of carbon, nitrogen, and phosphorus and transfer between trophic levels, in continental shelf waters south of New York. Rapp. P.v. Réun. Cons. int. Explor. Mer 153: 183-189

Dubé, J. (1982). Etude de la distribution de quelques métaux dans le zooplancton de deux écosystèmes du Saint-Laurent. Mémoire INRS-Océanologie, Université du Québec

Fisher, N. S., Bjerregaard, P., Fowler S. W. (1983a). Interaction of marine plankton with transuranic elements. 3. Biokinetics of americium in euphausiids. Mar. Biol. 75: 261-268

Fisher, N. S., Burns, K. A., Cherry, R. D., Heyraud, M. (1983b) Accumulation and cellular distribution of ${ }^{241} \mathrm{Am},{ }^{210} \mathrm{Po}$, and ${ }^{210} \mathrm{~Pb}$ in two marine algae. Mar. Ecol. Prog. Ser. 11: $233-237$

Fisher, N. S., Fowler, S. W. (1987). The role of biogenic debris in the vertical transport of transuranic wastes in the sea. In: O'Connor, T. P., Burt, W. V., Duedall, I. W. (eds.) Oceanic processes in marine pollution, Vol. 2. Krieger, Malibar, p. 197-207

Fisher, N. S., Nolan, C. V., Fowler S. W (1991a). Assimilation of metals in marine copepods and its biogeochemical implications. Mar. Ecol. Prog. Ser. 71: 37-43

Fisher, N. S., Nolan, C. V., Gorsky, G. (1991b). The retention of cadmium and zinc in appendicularian houses. Oceanol. Acta 14: 427-430

Fowler, S. W. (1977). Trace elements in zooplankton particulate products. Nature, Lond. 269: 51-53

Fowler, S. W. (1986). Trace metal monitoring of pelagic organisms from the open Mediterranean Sea. Environ. Monit. Assess. 7: 59-78 
Fowler, S. W., Papadopoulou, C., Zafiropoulos, D. (1985). Trace elements in selected species of zooplankton and nekton from the open Mediterranean Sea. In: Lekkas, T D. (ed.) Heavy metals in the enviromment, Vol. 1. CEP Consultants, Edinburgh, p. 670-672

Gorsky, G., Fisher, N. S., Fowler, S. W. (1984). Biogenic debris from the pelagic tunicate, Oikopleura dioica, and its role in the vertical transport of a transuranium element. Estuar. coast. Shelf Sci. 18: 13-23

Hamanaka, T., Tsujita, T (1981). Cadmium and zinc concentrations in zooplankton in the subarctic region of the North Pacific. J. oceanogr. Soc. Japan 37: 160-172

Hoeger, U. (1983). Biochemical composition of ctenophores. J. exp. mar. Biol. Ecol. 72: 251-261

Hunter, K. A. (1980). Processes affecting particulate trace metals in the sea surface microlayer. Mar. Chem. 9: 49-70

Krishnaswami, S., Baskaran, M., Fowler, S. W., Heyraud, M. (1985). Comparative role of salps and other zooplankton in the cycling and transport of selected elements and natural radionuclides in Mediterranean waters. Biogeochemistry 1. $353-360$

Laval, Ph. (1978). The barrel of the pelagic amphipod Phronima sedentaria (Forsk.) (Crustacea: Hyperiidea). J. exp. mar. Biol. Ecol. 33: 187-211

Madin, L. P. (1982). Production, composition and sedimentation of salp fecal pellets in oceanic waters. Mar. Biol. 67 : $39-45$

Madin, L. P., Cetta, C. M., McAlister, V. L. (1981). Elemental and biochemical composition of salps (Tunicata: Thaliacea). Mar. Biol. 63: 217-226

Morris, R. J., Bone, Q., Head, R., Braconnot, J. C., Nival, P. (1988). Role of salps in the flux of organic matter to the bottom of the Ligurian Sea. Mar. Biol. 97: 237-241

Nival, P., Braconnot, J. C., Andersen, V., Oberdorff, T., Choe, S. M., Laval, P. (1985). Estimation de l'impact des Salpes sur le phytoplancton en mer Ligure. Rapp. Comm. int.

This article was submitted to the editor
Mer Médit. 29: 283-286

Rainbow, P. S. (1989). Copper, cadmium and zinc concentrations in oceanic amphipod and euphausiid crustaceans, as a source of heavy metals to pelagic seabirds. Mar. Biol. 103: $513-518$

Reinfelder, J. R., Fisher, N. S. (1991). The assimilation of elements ingested by marine copepods. Science 251: $794-796$

Roméo, M. (1985). Contribution à la connaissance des métaux traces ( $\mathrm{Cd}, \mathrm{Cu}, \mathrm{Hg}, \mathrm{Pb}, \mathrm{Zn}$ ) dans l'écosystème marin au niveau du plancton. Approches analytiques et expérimentales. Thèse ès Sciences Physiques, Université de Nice

Roméo M., Gnassia-Barelli, M., Carré, C. (1987). Trace metals: $\mathrm{Cd}, \mathrm{Cu}, \mathrm{Pb}$ and $\mathrm{Zn}$ in gelatinous macroplankton from the Northwestern Mediterranean. Wat. Res. 21: $1287-1292$

Roméo, M., Gnassia-Barelli, M., Nicolas, E. (1985). Concentrations en plomb du plancton de la mer Ligure (Méditerranée Nord-Occidentale). Chemosphere 14(9): 1423-1431

Roméo M., Gnassia-Barelli, M., Nicolas, E., Carré, C. (1988). Importance du macroplancton gélatineux dans le stockage et le transfert de métaux traces en Méditerranée nord-occidentale. Rapp. Comm. int. Mer Médit. 31. 35

Roméo, M., Nicolas, E. (1986). Cadmium, copper, lead and zinc in three species of planktonic crustaceans from the East Coast of Corsica. Mar. Chem. 18: 359-367

Trégouboff, G., Rose, M. (1957). Manuel de planctonologie méditerranéenne. Centre National de la Recherche Scientifique, Paris

Youngbluth, M. J. \{1984\}. Water column ecology: in situ observations of marine zooplankton from a manned submersible. In: Flemming, N. C. (ed.) Divers, submersibles and marine science. Mem. Univ. Newfoundland, Occ. Pap. Biol. 9: 45-57

Manuscript first received: November 29, 1991

Revised version accepted: April 6, 1992 